\title{
NAUCZANIE PROBLEMOWE W PRAKTYCE
}

\begin{abstract}
Streszczenie: :W artykule dokonano analizy przypadku praktycznego wykorzystania metody uczenia się opartego na nauczaniu problemowym, które zastosowano w praktyce produkcyjnej. Nauczanie problemowe $\mathrm{z}$ angielskiego problem based learning (PBL) to skuteczna strategia uczenia, powszechnie stosowana od wielu dekad w edukacji na poziomie podstawowym, średnim jak i na uczelniach wyższych. W pracy dokonano analizy przydatności tej metody w szkoleniu pracowników produkcyjnych. PBL to jedna $\mathrm{z}$ wielu technik szkoleniowych prowadzonych poza stanowiskiem pracy a zwanych w literaturze przedmiotu Off the Job. Zaprezentowana zostanie skuteczność PBL w procesie szkolenia pracowników produkcyjnych oraz przedstawione zostaną zalety dochodzenia do wiedzy za pomocą ciągłego stymulowania procesu kształcenia, za pomocą zadawania pytań i stawiania przed uczestnikami szkolenia wyzwań/problemów.
\end{abstract}

Słowa kluczowe: definicja i geneza PBL, metody szkoleniowe, PBL w praktyce produkcyjnej, wyzwania cywilizacyjne

\section{Wprowadzenie}

Współczesna cywilizacja to niespotykane w dziejach ludzkości tempo rozwoju nauki i techniki. Ogromne osiągnięcia w obu tych zakresach powodują, iż praca w nowoczesnym zakładzie produkcyjnym wymaga od pracownika produkcyjnego kwalifikacji, które znacząco wybiegają poza ramy jego dotychczasowego doświadczenia i wiedzy nabytej $w$ szkołach [1]. Nowoczesne środowiska przemysłowe oraz inteligentne rozwiązania wymagają od pracownika wiadomości oraz sprawności, które znacząco wynoszą się ponad wąski wycinek jego codziennych czynności i obowiązków. Oczekuje się od nich znajomości zasad funkcjonowania i umiejętności płynnego przechodzenia pomiędzy wykonywanymi czynnościami, obsługą różnych maszyn i urządzeń. Pracodawca oczekuje od pracownika, aby umiejętnie panował, również nad aspektami nie tylko technicznymi, ale i również aspektami ekonomicznymi niezwykle istotnymi w obecnych czasach [2].

Obecne zakłady produkcyjne w znaczącej mierze opierają swoją strukturę na tworzeniu wartości dodanej, poprzez efektywne wykorzystanie potencjału ludzkiego, dlatego też firmy poważnie podchodzące do tego tematu koncentrują się na posiadanym kapitale ludzkim poddając go sekwencyjnemu i ustawicznemu procesowi szkolenia i doskonalenia jego umiejętności - kształtowaniu jego potencjału [3].

Należy również zauważyć, że pracownik aby stać się konkurencyjnym na obecnym rynku pracy musi zadbać o rozwój swojej wiedzy i kompetencji, które będą miały bezpośredni lub pośredni wpływ na jego karierę zawodową opartą na pracy $\mathrm{w}$ wielu organizacjach w dobie postępującej globalizacji.

\footnotetext{
${ }^{1}$ mgr, Jeremias Sp. z o.o. z siedzibą w Gnieźnie, s.zembski@wp.pl
} 


\subsection{Metody szkoleniowe powszechnie stosowane w praktyce produkcyjnej}

Zasadniczym celem szkolenia i doskonalenia zawodowego powinien być rozwój potencjału ludzkiego i przygotowania pracownika produkcyjnego do dalszego procesu odgrywania ról jakie będą przed nim stawiane we współczesnej organizacji, zakładzie produkcyjnym [4, 5].

$\mathrm{W}$ procesie wdrożenia pracownika produkcyjnego wyróżnia się następujące cele szkolenia [6, 7]:

- wyposażenie nowo zatrudnionych w specyficzne elementy potencjału ludzkiego;

- pogłębienie i rozszerzenie dotychczasowej wiedzy zawodowej oraz umiejętności pracownika;

- integrowanie cech osobowości, zdolności wiedzy i umiejętności danego pracownika w celu rozwijania tych kompetencji, które można zastosować bez dodatkowego uczenia się;

- uzyskanie nowego zawodu lub nowej specjalności zawodowej.

Formy szkolenia zawodowego $\mathrm{w}$ zakładzie produkcyjnym dzieli się w następujący sposób [5, 6]:

- przyuczenie do zawodu - ma na celu nauczenie pracownika podstawowych umiejętności zawodowych, które będą niezbędne do poprawnego wykonywania czynności produkcyjnych na powierzonym stanowisku pracy;

- doskonalenie umiejętności - szkolenie umożliwiające pogłębienie posiadanej dotychczas wiedzy i doskonalenie nabytych wcześniej umiejętności, niejednokrotnie prowadzone przez bardziej doświadczonego pracownika;

- rozwijanie kompetencji - doskonalenie dotychczas zdobytych umiejętności;

- przekwalifikowanie - szkolenie pozwalające na nabycie nowych umiejętności zawodowych lub zdobycie nowego zawodu.

Natomiast techniki szkoleniowe dzieli się na: indywidulane i grupowe oraz na techniki stosowane bezpośrednio na stanowisku pracy ( $\mathrm{z}$ ang. On the Job) lub prowadzone poza stanowiskiem pracy ( $\mathrm{z}$ ang. Off the Job). Do indywidulanych technik szkoleniowych prowadzonych na stanowisku pracy zalicza się $[4,5]$ :

- trening orientacji i adaptacji nowych pracowników;

- szkolenie bez odrywania od pracy;

- szkolenie w zawodzie;

- konsultacje z przełożonym;

- mentoring zwany wychowaniem w pracy;

- coaching;

- rotacja na stanowiskach pracy;

- specjalistyczny instruktaż;

- zastępstwo na stanowisku pracy; 
- program treningowy.

Natomiast techniki szkolenia grupowego przeprowadzane na stanowisku to [8]:

- prace projektowe prowadzone w celach szkoleniowych;

- grupowe formy pracy.

Techniki szkoleniowe prowadzone poza stanowiskiem pracy również dzieli się na: indywidulane i grupowe. Do indywidulanych należą $[4,8]$ :

- wykłady - to forma przekazywania usystematyzowanej wiedzy zgormadzonemu audytorium, przy ograniczonym zaangażowaniu słuchaczy. Celem wykładu jest zapoznanie z teoretycznymi aspektami dotyczącymi danej dziedziny lub pojęcia;

- techniki multimedialne w tym E-learning - są to techniki wykorzystujące cuda techniki oferowane przez współczesny świat, należą do nich: filmy, nagrania, Internet, platformy E-larningowe. Zaletą tego typu rozwiązań jest ich elastyczność w nauczaniu, dzięki powtórkom, zwolnionemu odtwarzaniu słuchacz może dopasować materiał do swoich zdolności poznawczych i tempa uczenia się;

- zaprogramowany instruktaż - rolę trenera $\mathrm{w}$ tej technice przejmuje program komputerowy np. zainstalowany na tablecie na stanowisku pracy, który przeprowadza pracownika krok po kroku, poprzez czynności, jakie powinien wykonać podczas pracy na stanowisku;

- analiza przypadku ( $\mathrm{z}$ ang. Case study) - jedna z bardziej popularnych technik szkoleniowych, oparta została na analizie hipotetycznej lub prawdziwej sytuacji przez osoby poddane szkoleniu. Hipotezy w tym procesie stworzone zostają poddane dalszej dyskusji i analizie;

- studia i kursy.

Natomiast grupowe techniki szkoleniowe of the job, podzielone zostały na [4]:

- Metody symulacyjne przebiegają w warunkach i sytuacjach szkoleniowych w dużej mierze zbliżonych do codziennej rzeczywistości, jaka otacza pracownika produkcyjnego wysłanego na szkolenie. Są to stymulowane sytuacje, które zdarzyły się lub mogą się zdarzyć na stanowisku pracy. Celem takiego szkolenia jest kształtowanie pożądanych postaw w trakcie zaistnienia danych sytuacji [9].

- Gry ról - to gra oparta na odgrywaniu poprzez uczestników szkolenia określonych ról organizacyjnych wykreowanych na potrzeby szkolenia przez trenera. Jest to metoda pozwalająca na doskonalenie pożądanych umiejętności np. komunikacyjnych, negocjacyjnych, rozwiązywania trudnych sytuacji problemowych [9].

- Trening outdoor- powszechnie stosowany przez korporacje. Służy do intensywnego i zespołowego działania, zazwyczaj na łonie natury, w celu osiągniecia wyznaczonego celu. Treningi tego typu są diametralnie inne od znanej uczestnikowi takiego szkolenia codzienności, przez co pozwalają odkryć ukryty potencjał pracowników. Niejednokrotnie są panaceum na wypalenie zawodowe 
lub też ostatnią deską ratunku na zbudowanie zespołu, który na co dzień będzie odnosił sukcesy dzięki pracy zespołowej i myśleniu poza książkowemu.

Obecnie jedną z najczęściej stosowanych technik szkoleniowych poza stanowiskiem pracy, Off the Job zalicza się technikę nauczania problemowego, która jest mieszanką metody symulacyjnej i gry ról opartej na stopniowym dochodzeniu do wiedzy, poprzez rozwiązywanie problemu.

\subsection{Geneza i definicja nauczania problemowego}

Pionierami wdrożenia nauczania problemowego ( $\mathrm{z}$ ang. Problem Based Learning) byli Barrows and Tamblyn [10], którzy użyli tej metody nauczania na początku lat 60-tych na uniwersytecie McMaster w Hamilton. Stworzony przez nich program miał na celu pobudzić młodych studentów medycyny, którzy przez okres pierwszych swoich trzech lat pochłaniali ogromną ilość materiału, nie potrafiąc w żaden sposób jej zastosować. Celem programu było stymulowanie studentów do wykorzystania nabytej wiedzy do pełnienia przyszłych ról. Program pozwalał również na analizę problemów będących w przyszłości rzeczywistymi wyzwaniami, przed jakimi staną przyszli młodzi lekarze. Duże zainteresowanie wśród studentów studiów medycznych spowodowało dynamiczny rozwój PBL na innych kierunkach studiów, takich jak: prawo, edukacja, ekonomia, kierunki inżynierskie.

Nauczanie problemowe zdefiniowane zostało jako filozofia nauczania, która opisuje zespół zasad i standardów niezbędnych w procesie efektywnego nauczania [11]. Zasady te mogą być modelowane w dowolny sposób w zależności od potrzeb i celów jakie mają być osiągnięte [12].

Należy, również wspomnieć, że proces nauczania problemowego był również mocno analizowany w polskiej edukacji. Powstało wiele opracowań na temat kształcenia problemowego. Prekursorami nauczania problemowego w polskiej edukacji byli Wincenty Okoń i jego uczeń propagator i autor pierwszego opracowania poruszającego tematykę efektywności nauczania problemowego Czesław Kupisiewicz [13]. Uczenie problemowe to skoncentrowana metoda uczenia się poprzez doświadczenie, czyli rozwiązywanie otwartego problemu narzuconego przez nauczyciela, trenera. Cechą główną tej metody nie jest koncertowanie się na ściśle określonej metodzie rozwiązania problemu. Celem w samym sobie jest rozwój umiejętności i cech osoby szkolonej zgodnie z oczekiwaniami nauczyciela, trenera. Metoda ta obejmuje zdobywanie wiedzy poprzez działanie, pracę zespołową, komunikację [12, 14]. Proces ten pozwala uczniom rozwijać umiejętności wykorzystywane w ich przyszłej praktyce. Wzmacnia krytyczną ocenę, odtwarzanie literatury i zachęca do ciągłego uczenia się w środowisku zespołowym [15]. Metoda uczenia problemowego oparta jest na pracy w małych grupach, w których ich 
członkowie przyjmują określone role mniej lub bardziej formalne. Role te często są zmieniane i dopasowywane do rzeczywistych warunków, w jakich przychodzi im rozwiązywać problem, podejmować wyzwanie wykonania danego zadania. Metoda nauczania problemowego oparta jest na 5 etapach, krokach do których należą [16]:

- krok 1 - odczucie trudności;

- krok 2 - sformułowanie problemu;

- krok 3 - poszukiwanie rozwiązań, tworzenie hipotez potencjalnych rozwiązań;

- krok 4 - logiczna i jeżeli to możliwe empiryczna weryfikacja hipotez;

- krok 5 - obserwacja wprowadzonych rozwiązań, przyjęcie lub odrzucenie rozwiązania, co w konsekwencji prowadzi do powrotu do kroku trzeciego lub nawet do drugiego.

Metoda problemowa to modelowy przykład nauczania poszukującego, doskonale wpasowująca się w naturalne fazy ludzkiego rozwoju niezależnie od wieku, wykształcenia, czy też pełnionej roli społecznej. Prowadzone tą metodą zajęcia stanowią naturalny ciąg następujących po sobie czynności, znanych nam z codziennego życia, które prowadzą do rozwiązania określonego problemu. W. Okoń podkreślał z wyraźnym naciskiem, że finałem dobrze przeprowadzonego szkolenia jest umiejętność zastosowania wiedzy przez kursanta w życiu codziennym [15].

\section{Geneza i definicja nauczania problemowego}

Podstawowym warunkiem efektywnego nauczania oraz kształcenia samodzielności myślenia pracowników produkcyjnych $\mathrm{w}$ procesie wdrożenia jest problemowe ujmowanie materiału, umożliwiające pracownikom formułowanie, rozwiązywanie i sprawdzanie określonych zagadnień w toku własnej działalności poznawczej opartej na czynnościach myślowych, jak i praktycznych. Podstawą myślenia praktycznego jest działanie, a więc wszelkie celowe czynności wewnętrzne i zewnętrzne stanowiące główny sposób sprawdzenia konkluzji, domysłów i pomysłów dotyczących rozwiązania danego zagadnienia. Czynny stosunek do świata, umiejętności radzenia sobie w nowych, trudnych, nieznanych jeszcze sytuacjach, można bardzo mocno wzmocnić, poprzez wdrażanie pracowników do rozwiązywania określonych zadań wynikających $\mathrm{z}$ określonych sytuacji problemowych.

Nauczanie problemowe powinno być postrzegane jako projekt działania, w którym podmiot zamierza odkryć drogę niekoniecznie zgodną $\mathrm{z}$ jego wcześniejszymi doświadczeniami i wiedzą. Zajęcia $\mathrm{z}$ wykorzystaniem metody nauczania problemowego zwykle opierają się na małych grupach pracowników, maksymalnie od $8-10$ osób. Zaletą małej grupy, poza łatwością przekazywania wiedzy i zapanowania nad nią jest również mniejsza destabilizacja pracy zakładu, w którym dany problem jest rozwiązywany - np. pracownicy mogą być z kilku 
niezależnych zmian produkcyjnych. Początek spotkania poświęcony zostaje omówieniu wyzwania, jakie przed pracownikami postawi „sponsor" (potoczne określenie Dyrektora Zakładu, Prezesa). Celowo zostaje pominięte słowo problem, ponieważ w warunkach polskich słowo „problem” jest negatywnie rozumiane i od samego początku powoduje wyzwolenie negatywnych emocji zaburzających pozytywną atmosferę pracy jaka powinna występować na efektywnym szkoleniu. Sformułowanie wyzwania, zajmuje najwięcej czasu, ponieważ od tej części zależy powodzenie całego szkolenia. Wyzwanie formułowane zostaje razem z grupą dzięki czemu angażowany jest każdy $\mathrm{z}$ członków szkolenia, tak aby posiadał on wiedzę dotyczącą istoty problemu. Zazwyczaj zdarza się tak, że niektórzy członkowie grupy posiadają szczątkową wiedzę, która może pomóc w zdefiniowaniu lub też częściowym rozwiązaniu problemu. Po zdefiniowaniu problemu grupa zostaje podzielona na dwie niezależne podgrupy, które w swoim obszarze dzielą się zadaniami pomiędzy swoich członków. W trakcie rozwiązywania problemu grupy przetwarzają zaprezentowane informacje, w taki sposób, aby móc je przedstawić pozostałym członkom grupy i zaprezentować hipotetyczne rozwiązania danego wyzwania lub też, jeżeli zachodzi taka potrzeba dokonują ponownego przedefiniowania wyzwania w procesie dyskusji z prowadzącym. Po zakończeniu procesu myślowego grupa spotyka się ponownie na konkluzji w sprawie ostatecznego wniosku. Prezentowanie konkluzji odbywa się na forum przed prowadzącym i pozostałymi uczestnikami szkolenia. Podczas prezentacji dochodzi zazwyczaj do żywiołowej dyskusji i argumentowania przyjętych potencjalnych hipotez rozwiązania danego wyzwania. W trakcie szkolenia mogą odbywać się inne spotkania, celem wyjaśnienia wyzwania, jakie zostało postawione przed pracownikami. Może dojść również do sytuacji, w której rozumowanie zostaje przerwane $\mathrm{z}$ powodu braku informacji niezbędnych do poprawnego zdefiniowania i stworzenia potencjalnych hipotez niezbędnych do logicznej i empirycznej weryfikacji. Na rysunku numer 1. przedstawiano algorytm rozwiązywania problemu za pomocą techniki PBL.

W konsekwencji, jeżeli pracownicy nie osiągną nawet zamierzonego celu to dojdą do częściowych rozwiązań, które wzbogacą ich wiedzę i kompetencje, pozwalając na podjęcie kolejnych kroków zbliżających ich do celu. Nauczanie problemowe obejmuje zasady dobrego uczenia się, dlatego też tak chętnie i skutecznie jest stosowane, ponieważ poza dobrymi rezultatami dotyczącymi szybkiego wdrożenia pracowników do procesu produkcyjnego, zachęca również do samowystarczalności promuje aktywne i głębokie zgłębianie wiedzy poprzez rozwiązywanie problemów, realizację stawianych wyzwań. Kolejną ważną cechą PBL jest nauczania partnerskie. Nauczyciel jest częścią grupy, czynnie zachęca uczniów do analizowania informacji i w dużej mierze bierze czynny udział w tworzeniu hipotez i wyborze ścieżek prowadzących do osiągnięcia postawionego przed grupą wyzwania. Prowadzone 
$\overline{\text { szkolenia umożliwiają } \mathrm{w} \text { znaczący sposób wykorzystywanie zaprezentowanych }}$ wcześniej informacji, wzmacniają procesy pamiętania i stosowania raz nabytej i przećwiczonej wiedzy w nowych sytuacjach.

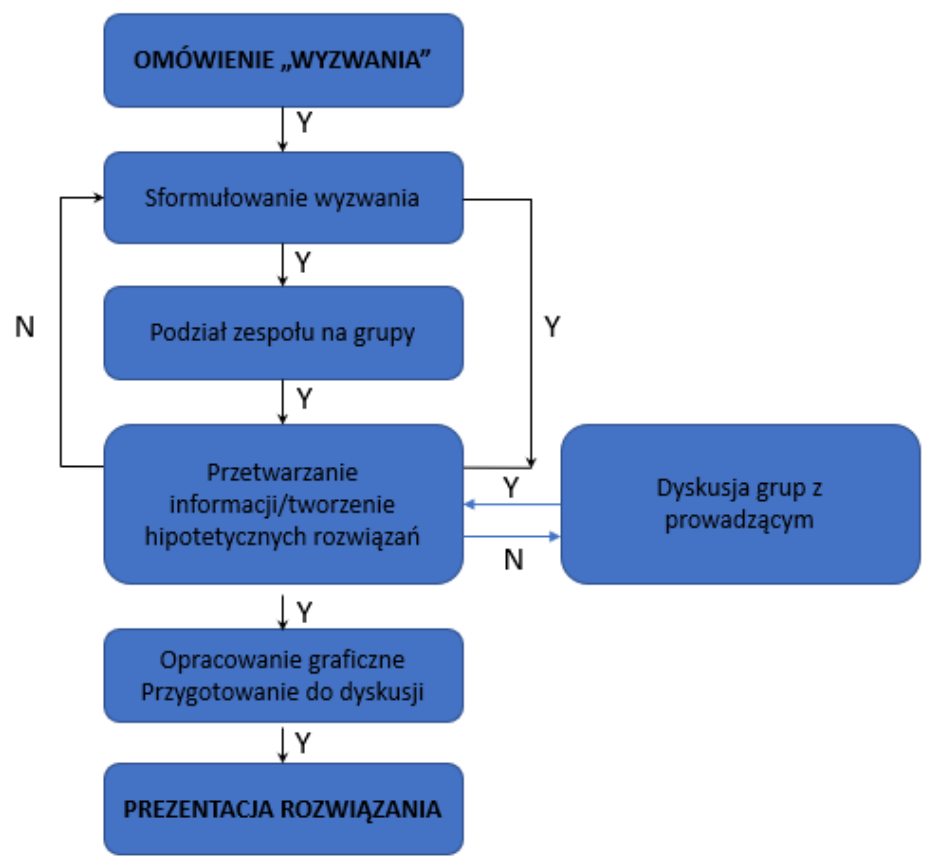

Rys. 1. Algorytm rozwiazywania Wyzwania/Problemu za pomoca Problem Based Learning Źrodto: Opracowanie wtasne

Istnieje wiele drogowskazów na drodze PBL, tworzących podpowiedzi prowadzące do rozwiązania problemu lub też otwierających drogi do kolejnych hipotez i założeń. Celem samym w sobie szkolenia problemowego nie jest jednoznaczna odpowiedź na zadane pytania czy też rozwiązanie problemu, lecz nauczenie pracowników procesu ciągłego doskonalenia, dochodzenia do wiedzy na drodze ciągłego poszukiwania i próbowania nowych lepszych rozwiązań, tak aby słowo doskonałość kojarzyło się z ciągłym poszukiwaniem nowych lepszych rozwiązań.

\section{Rezultaty nauczania problemowego}

$\mathrm{Na}$ postawie obserwacji należy stwierdzić, że nauczanie problemowe umożliwia szybkie przyswajanie wiedzy niezbędnej pracownikowi w procesie produkcyjnym, ponieważ jest on celowo stawiany przez trenera w sytuacjach, które zmuszają go do myślenia, samodzielnego szukania odpowiedzi, formułowania 
hipotez, a nie tylko do odtwarzania zakresu teorii, którą przyswoił w czasie wykładu. Formułowanie i uzasadnienie hipotez zmusza uczestnika szkolenia do odwoływania się do posiadanej wiedzy, doświadczeń, przeżyć, czego następstwem jest głębsze utrwalenie nabytej wiedzy i wykształconych umiejętności. Dyskusja nad zgłaszanymi hipotezami wdraża uczestników szkolenia do poprawnego argumentowania swoich założeń i posługiwania się nimi. Pozwala również w sposób nieskrępowany wypowiadać swoje spostrzeżenia, wnioski, przyjmować krytykę i kontrargumentację, która w znaczący sposób przyspiesza proces myślowy. Kolejną istotną zaletą PBL jest aktywizowanie pracowników średnich i słabych, którzy zazwyczaj podczas prowadzenia standardowych warsztatów tradycyjnymi metodami nikną pośród całej rzeszy uczestników szkolenia, a to w głównej mierze oni tworzą trzon grupy podanej procesowi szkolenia [17]. Dotarcie do pracowników średnich umożliwia specyfika nauczania problemowego, która odwołuje się do problemów formułowanych na podstawie zjawisk i doświadczeń, z jakimi wcześniej kursanci mieli do czynienia. Istotnym, jak nie najważniejszym skutkiem opisywanej metody jest przygotowanie pracowników, do prowadzenia systematycznej i planowanej obserwacji, ciągłego uczenia się i dostrzegania związków, zależności miedzy rzeczami, zjawiskami i procesami zachodzącymi $\mathrm{w}$ procesie produkcyjnym. Umiejętności $\mathrm{w}$ ten sposób nabyte, mogą wykorzystywać do przewidywania następstw postępowań lub też do zrozumienia nowych zjawisk i procesów, jakie zachodzą w zakładach produkcyjnych XXI wieku [18]. Tak zdobyta wiedza, staje się narzędziem przydatnym w przekształceniu otaczającej go rzeczywistości, w jakiej na co dzień się znajduje i pracuje. Rozwiązywanie problemów w drodze czynności myślowych, sprawdzanych następnie za pomocą czynności praktycznych przyczynia się również znacząco do uświadomienia pracownikowi celowości podjętych działań i wysiłku, jaki musiał ponieść wraz z grupą, aby wykreować, stworzyć hipotezy, które stały się potencjalnymi rozwiązaniami. Ukierunkowuje i uczy go jak odpowiednio ogniskować uwagę na problemach zasadniczych.

Zaprezentowana metoda działania oraz sposób jej wdrożenia w rozwoju pracowników produkcyjnych $\mathrm{w}$ odróżnieniu od innych metod szkoleniowych przyczynia się w ogromnej mierze do wyrobienia wśród szkolonych osób nawyku samokształcenia [19]. Jest to bezcenna umiejętność, która wyrobiona w pracownikach pozwala na dostrzeganie i rozwiązywanie problemów oraz sprawdzania uzyskanych rezultatów. Przyzwyczaja do samodzielności działania i posługiwania się właściwymi technikami w procesie codziennego doskonalenia zawodowego. PBL jest efektywnym podejściem do nauczania i uczenia się szczególnie, gdy weźmie się pod uwagę długość przechowywania wiedzy i umiejętność jej stosowania w codziennych czynnościach [19]. Pozwala na szybkie wdrożenie pracownika do procesu, który 
wykazując się dużym zaangażowaniem podczas rozwiązywania problemu, osiąga wyższe wyniki, niż uczestnicy szkoleń wdrażanych tradycyjnymi metodami.

\section{Podsumowanie}

Gospodarka XXI wieku jest nasycona wiedzą i nowoczesną technologią, dlatego też w perspektywie długofalowej, zakłady produkcyjne, aby budować swoja trwałą pozycję i móc być konkurencyjne w stale zmieniającym się środowisku muszą podnosić poziom kwalifikacji zatrudnionych w nich pracowników. Dlatego też w tym kontekście bardzo istotny staje się kapitał ludzki. Tylko organizacje, które zbudowane są na wiedzy, będą potrafiły w sposób efektywny wykorzystać potencjał zatrudnianych pracowników. Na drodze do budowania kapitału ludzkiego oraz kwalifikacji zawodowych pojawia się powszechnie stosowana w wielu krajach metoda nauczania problemowego, która pozwala na szybkie i efektywne zwiększenie zaangażowania i samouczenia się pracowników [11].

Zaprezentowane case study nauczania problemowego wskazuje, że spełnia ono postawione przed nim zadania współczesnego rynku pracy. PBL jest metodą prostą i łatwą do wdrożenia zapewniającą maksimum efektów wdrożeniowych przy niskim nakładzie finansowym. Celem samym w sobie jest przygotowanie współczesnego pracownika do dynamicznego środowiska ciągle zmieniającego się świata oraz wykształcenie zdolności doskonalenia się i ciągłego poszukiwania lepszych, doskonalszych rozwiązań. Podejścia samokrytycznego, dokonywania samooceny i wprowadzania niezbędnych działań korygujących, potrzebnych do osiągnięcia zadanego celu [12].

Należy pamiętać, że podczas wyboru metody i technik szkoleniowych powinno się zrobić wszystko, aby zapewnić możliwość aktywnego stymulowania i łatwego uczenia się. Niezwykle istotnym aspektem jest również wykorzystanie nabytej wiedzy na szkoleniu w codziennym życiu produkcyjnym. Tylko odpowiednio dobrana i wdrożona metoda nauczania prowadzona przez odpowiednich i kompetentnych trenerów zapewni stworzenie organizacji uczącej się, w której problemy będą traktowane jak wyzwania, szanse lub okazje do pójścia znacznie dalej niż konkurencja.

\section{Bibliografia}

[1] Trocki M. Nowoczesne zarzadzanie projektami. Polskie Wydawnictwo Ekonomiczne. Warszawa 2013.

[2] Makuch M. Współczesny rynek pracy. Zatrudnienie i bezrobocie w XXI wieku. Uniwersytet Wrocławski, 2014. 
[3] Malinowski M. Potencjat ludzki a efektywność ekonomiczna przedsiębiorstw wykorzystanie metod taksonomicznych $w$ ujęciu regionalnym. Uniwersytet Przyrodniczy w Poznaniu, 2016.

[4] Abdullah H. Implementing Training in Manufacturing Firms: Training Methods, Venue and provider, University Putra Malaysia, 2014.

[5] Oczkowska R., Bukowski U. Rozwój zasobów ludzkich. Wydawnictwo Delfin, Warszawa 2014.

[6] Rae L. Planowanie i projektowanie szkoleń. Wolter Kluwer Business 2015.

[7] Warwas I. Rogozińska-Pawełczyk A. Zarzadzanie zasobami ludzkimi w nowoczesnej organizacji. Aspekty organizacyjne i psychologiczne. Wydawnictwo Uniwersytetu Łódzkiego, 2016.

[8] Kothelawala J. Constructivist Teaching/ Learning Theory and Participatory teaching Methods, Journal of Curriculum and Teaching, Vol. 6, No. 1; 2017.

[9] Wawer M. Edukacyjne Gry Symulacyjne w rozwoju kompetencji pracowników. Wyższa szkoła Przedsiębiorczości i Administracji w Lublinie 2013.

[10]Barrows H.S. A taxonomy of problem- based learning methods. Medical Education 20, p. 481-486, 2001.

[11]Graff E., Kolmos A. Management of change implementation of problem based and project-based learning in engineering. University Science and Mathematics Education in Transition, p. 261-280, Netherlands 2007.

[12] Kolmos A., Graff E. Research on PBL practise in engineering education, Sense Publishers Rotterdam p.: 9-21, 2008.

[13] Kupisiewicz Cz. O efektywności nauczania problemowego, Państwowe Wydawnictwo Naukowe, Warszawa 1962.

[14]Dolmans D.J.M., Grave W. Problem based learning: future challenges for educational practise and research. Medical Education 39, p.: 732-741, 2014.

[15]Okoń W. U podstaw problemowego uczenia się. Warszawa 1964.

[16]Dahms M.L. Problem based Learning in Engineering Education, Attracting Young people to Engineering, Associação Brasileira de Educação em Engenharia, p.:10-21, 2014.

[17] Sadeh I., Ziohn M. The development dynamic Inquiry Performance within an open inquiry settings, Journal of research in science Teaching 46, p. 1137-1160, 2009

[18] Kim M., Tan A. New vision of challenges in inquiry-based curriculum change in Singapore. International Journal of science Education 35, p.: 289-311, 2013

[19] Yew H., J., Goh K. Problem based learning: An overviewu of its process and impact on learning, Science Direct, Health Profession education 2, p.: 75-79, 2016 


\title{
PROBLEM BASE LEARING IN PRACTICE
}

\begin{abstract}
Article analyzes the case of the practical use of a learning method based on problem-based learning, which was applied in production practice. Problem based learning (PBL) is an effective learning strategy, commonly used for decades in primary, secondary and higher education. The work analyzes the suitability of this method in the training of production workers. PBL is one of many training techniques conducted outside of the work post and called in the literature Off the Job subject. Will be presented the effectiveness of PBL in the training process production worker's and the advantages of reaching knowledge through the continuous stimulation of the education process, by asking questions and presenting challenges on the front of training participants.
\end{abstract}

Key words: definition and genesis of PBL, training methods, PBL in production practice, civilization challenges.

Data przestania publikacji do Redakcji: 05.08.2018

Data akceptacji publikacji przez Redakcję: 21.09.2018 